\title{
RZESZÓW GARRISON OF THE HOME ARMY IN THE PLANS TO RESTORE THE ARMED FORCES
}

\begin{abstract}
The article is an attempt to show the role of the underground garrison of the Home Army in Rzeszów during the German occupation of 1939-1944. The garrison's preparations and tasks related to the general uprising plan in the Union of Armed Struggle-the Home Army Inspectorate of Rzeszów were reconstructed. The main tasks resulting from the planned mobilization and so-called reconstruction of the armed forces were also presented, i.e. some attempts to form regular Polish Army troops referring to the tradition from before September 1939. The detailed arrangements for the Rzeszów garrison resulting from orders of the Supreme Commander from London were described, but also national command structures of the Home Army which also included the reconstruction of barracks and other military institutions and facilities. The organization and structure of the underground Rejuvenation Commission of Supplements, quartermaster services as well as garrison hospitals were presented. The authors assessed the mobilization, but also the combat opportunities, of the HA Inspectorate of Rzeszów as a part of the general uprising and later the „Burza” campaign. The text also provides a description of the real state of reconstruction of the armed forces and formation of the so-called large units of the Home Army - infantry divisions, cavalry brigades, infantry regiments - on the basis of regular military units in the summer of 1944. The issue of the armed disclosure of the Home Army forces in September 1944 was also discussed, which referred to the plan for the reconstruction of the armed forces.
\end{abstract}

Keywords: Polish Army, a garrison, the Home Army.

In the Polish military tradition, the garrison does not have a precisely defined term. Sometimes the ,garrison" refers only to the locality where troops are stationed. An equally popular explanation of the term is associated with military units stationed in a given area. Nowadays, the ,garrison" is used to refer to both the place - the city and its barracks - as well as the crew itself, i.e., military units formed and deployed in a specific place ${ }^{3}$.

Under the conditions of the occupation of the Second World War, the garrison of the underground army, that is the Union of Armed Struggle (UAS), and from February 1942,

\footnotetext{
${ }^{1}$ Prof. Grzegorz Ostasz, DSc, PhD, Department of Humanities, Faculty of Management, University of Technology of Rzeszow, Poland, e-mail: gost@prz.edu.pl

2 Tadeusz Olejarz, PhD, Department of Humanities, Faculty of Management, University of Technology of Rzeszow, Poland, corresponding autor, e-mail: olejarz@ prz.edu.pl

${ }^{3}$ Compare: J. Majka, Garnizon Rzeszów w latach 1918-1939, Rzeszów 2005; P. Bauer, Garnizon leszczyński we wrześniu 1939 r., Leszno 1983; T. Olejarz, Dzieje logistyki wojsk lądowych w latach 1944-1988 na przyktadzie 9. Dywizji, a typescript, Rzeszów 2013.
} 
the Home Army, initially played a secondary role. Nevertheless, positions of officers of the garrison appeared in the structures of commissions of districts, wards, or headquarters of the district inspectorates of the Home $\mathrm{Army}^{4}$. The significance of garrisons changed after joining the tasks related to the general uprising plan, and above all the implementation of the reconstruction of the Armed Forces (AFR).

The aim of the reconstruction of the Armed Forces in the country was to organize as soon as possible the so-called base of the insurgency, an army that will be able to take an open fight with the retreating enemy. The plan and objectives of the AF in the first version of the general uprising were specified by the General Command of the UAS-HA of 10 May 1941, and in the second of April 9, 1942. The main task of the AF was to organize the army according to the Ordre de Bataille ${ }^{5}$ pre-war, including military garrisons at that time ${ }^{6}$.

„Operational Report No. 154”, just like the previous „Operational Report No. 54” assumed that the Home Army would undertake insurgent combat with small units "in strength to the platoon or at most a grouping of several platoons ${ }^{7}$ ". It will only be on the liberated territory that it will start the reconstruction of armed forces ${ }^{8}$. The reconstruction of the armed forces - the phase of proper mobilization - was to constitute the next, essential period of operation of the Home Army. The amendment to „Operational Report No. 154” announced that ,an important part of the end of our insurgent actions will be the reconstruction of the armed forces in the State as the basis [...] of further armed action"'. The preparation of the reconstruction of the Armed Forces was conducted by units which were called ,mobilization units". They planned to reconstruct the divisions and brigades of the Polish Army - the so-called „Big Units” - from before September $1939^{10}$. The tradition of the existence of garrisons and military units in specific cities, confirmed by the presence of officers and non-commissioned officers, spoke about this.

The creation of mobilization plans was initiated by the Home Army Commandant on April 9, 1942. It states:

„The aim of the Reconstruction of the Armed Forces in the country is to organize [...] an army that will be able to oppose the enemy in an armed manner and set the boundaries of the state" 11 .

${ }^{4}$ Compare: W. Zarzycki, Z Wilna do Workuty. Wspomnienia komendanta garnizonu Okręgu Wileńskiego AK, Warszawa 2011; G. Ostasz, Obwód ZWZ-AK Rzeszów. Konspiracja wojskowa $i$ „Burza”, Rzeszów 1992; G. Ostasz, Z dziejów „Rozbratla” - Obwodu AK Rzeszów, Rzeszów 2003; G. Ostasz, Podziemna armia. Podokręg AK Rzeszów, Rzeszów 2010.

5 Ordre de Bataille (Fr. battle order, OdeB for short) -organization chart of troops or parts thereof, also in peaceful conditions. Nowadays, in the Polish Armed Forces this term is not use

${ }^{6}$ Compare: Polskie Sity Zbrojne w drugiej wojnie światowej, vol. 3, Armia Krajowa, Londyn 1950, pp. 211-214; Central Military Archive in Warszawa Rembertów, reference number III / 21/9, Tables of the Armed Forces in the country; A. Sanojca, Reconstruction of the Armed Forces in the Country, typescript, Institute of History of the Polish Academy of Sciences in Warsaw.

7 Armia Krajowa w dokumentach 1939-1945 [for more: AK w dokumentach], vol. VI, Uzupetnienia, Londyn 1989, p. 137.

${ }^{8}$ Polskie Sity Zbrojne..., pp. 211-214.

9 AKw dokumentach, vol. VI, p. 153. Por. M. Ney-Krwawicz, Powstanie powszechne w koncepcjach i pracach Sztabu Naczelnego Wodza i Komendy Gtównej Armii Krajowej, Warszawa 1999.

${ }^{10}$ AK $w$ dokumentach, vol. VI, p. 153.

${ }^{11}$ Polskie Sity Zbrojne..., p. 211. 
It should be added that some assumptions of the AFR plan were refined only in the summer of 1944. On June 10, 1944, the „Polish” London wired to the Home Commandant of the Home Army with the question „,is the affiliation of i[nfantry] r[egiment] to the Div[ision] pre-war [.]?” . In addition, the officers of the Supreme Commander's staff were interested in the tasks that the Home Army provided for the ,fourth infantry battalions in regiments, and why such battalions are reconstructed only by infantry regiments in the south-eastern areas"12.

The District Command of the UAS Kraków initiated works on the reconstruction of the Polish Army as early as in 1941. Unfortunately, as a result of the arrests made by the Germans in spring 1941, ,the study of the possibilities of AFR was delayed"13. Nevertheless, the plans were continued. Finally, it was agreed that the HA District of Kraków would undertake the reconstruction of personnel for five infantry divisions and one motorized brigade $^{14}$. As for the HA Rzeszów Inspectorate, in February 1944, Cpt. Łukasz Ciepliński („Pług”), a Home Army inspector from Rzeszów, announced an order - agreed with the command of the Rzeszów Sub-District HA - regulating the principles of the AFR ${ }^{15}$. He assumed that before the uprising, ,all branches of the inspectorate" are called 17 infantry regiment (ir), he predicted that ,everyone is going to fight” in addition to so-called mobilization budgets. Each ,branch and independent unit” intended for reconstruction should find officers and non-commissioned officers from before the war. Based on the instructions of the Krakow HA District, Cpt. Ciepliński suggested that the „mobilization” of the staff and services of the „Big Unit” (division, brigade) would be an officer and five non-commissioned officers. Only one officer, though six non-commissioned officers, was envisaged to recreate the regiment and so-called ,equivalent centers”. In turn, to prepare the mobilization of an independent battalion, or a squadron, or ,equivalent centers”, an officer and three noncommissioned officers were enough. During the insurgent fights, the units were to remain in place, implementing the AFR plan. After the reconstruction of the regular army units, mobilization units were to act as backup formations. The guidelines for AFR stated that for the duration of the reconstruction of the regular units of the Polish Armed Forces, the „functions of the players" would be of a ,temporary" nature.

The commanders will be those who ,stand out during the fight" ${ }^{16}$. According to Mieczysław Wałęga, among the candidates for the command post at the AFR in the Rzeszów Inspectorate, there was one of the officers - „deputies” - Col. Stanisław Maczek from the 10th Cavalry Brigade ${ }^{17}$.

\footnotetext{
${ }^{12}$ Study of Polish Underground in London [abbrev.:SPU], ref. 2.3.2.11.2, Depesza-szyfr, L.dz. 852/Op, „Lawina” - wyjaśnić z OSZ, 10 VI 44.

${ }^{13}$ AK w dokumentach, vol. II, Czerwiec 1941 - kwiecień 1943, Londyn 1973, p. 93, 110.

${ }^{14}$ Polskie Sity Zbrojne..., p. 212.

15 State Archives in Rzeszów [hereinafter: RSA], group 108, ref. 139, Wytyczne do OSZ inspektora kpt. Cieplińskiego z lutego $1944 r$. Also in February 1944, orders for the reconstruction of the armed forces (the so-called mobilization orders) were issued by the remaining inspectors of the Rzeszów HA Sub-range. RSA, group 108, ref.119, to Kmdtów Obwody, Jagra, 3 February 1944.

16 RSA, group 108, ref. 139, Wytyczne do OSZ inspektora kpt. Cieplińskiego z lutego 1944 r.

${ }^{17}$ Oral account of M. Wałęga (Rzeszów), 22 September 1998; G. Ostasz, Inspektorat ZWZ-AK Rzeszów w planach powstania powszechnego i odtwarzania sit zbrojnych, „Scientific Papers of RUT”, p. 14, 1991, pp. 123. Compare: J. Majka, Brygada motorowa ptk. Maczka: 10. Brygada Kawalerii 1937-1939, Rzeszów 2004.
} 
Of course, it was assumed to restore positions prior to September 1939. The Commander of the Rzeszów Sub-District and the inspectors paid attention to the need to ,increase motorisation" conditioned by military experience. They noted that from then on, the primary unit within the main weapons would not be a platoon, but a battalion, a squadron, a battery. The platoon was supposed to retain its rank only in armored weapons, sub-units of sappers, communications, and gendarmes ${ }^{18}$.

The Rzeszów HA Inspectorate appointed those responsible for the reconstruction of the armed forces; such a rule of conduct was in force in the HA Kraków District. The reconstruction operations were to be directed by the deputy inspectors. District commanders and mobilization officers became the proper executive body ${ }^{19}$. The main task within the AFR belonged to the Rzeszów HA District. In the first wave he was to mobilize two battalions of the 17 th Infantry Regiment ${ }^{20}, 20$ Uhlan Regiment $^{21}$ with two platoons of horse scouts, motorized artillery center in the following composition: 5 horse artillery squadron, two squadrons - one for 5 and 10 heavy artillery regiments ${ }^{22}, 1$ squadron of the 22 nd Light Artillery Regiment ${ }^{23}$, 2nd Division of armored trains, anti-tank artillery of the Krakow Cavalry Brigade, moreover a battalion of bridge and railway sapper, platoon of the 24th Infantry Division $^{24}$, battalion of the Military Security Service, squadron of motor service.

Meanwhile, the reconstructed 20 Uhlan Regiment - it was assumed - was to reconstruct the cavalry of the 22nd and 24th Infantry Divisions ${ }^{25}$. The so-called ,reserve” of Uhlans was intended for the 5 th Regiment of Riflemen ${ }^{26}$ formed in the HA Dębica District, where also the 3rd Battalion of the 17th Infantry Regiment was reconstructed. The mobilization of the 4th battalion of this regiment was the task of the Kolbuszowa District of the Home Army. Possible „surpluses” from the HA Rzeszów Inspectorate were allocated to reserve battalions. The AFR plan suggested that soldiers ,specialists” from units not being reconstructed by the Rzeszów HA Inspectorate would be transferred to the appropriate places, for example, seamen to Gdynia, Warsaw, and Pinsk. As a part of the second wave of mobilization, the HA Rzeszów Inspectorate planned to reconstruct the first artillery regiment from Stryj ${ }^{27}$.

${ }_{18}$ RSA, group108, ref. 139, Wytyczne do OSZ inspektora kpt. Cieplińskiego z lutego 1944 r.

19 Ibidem.

20 Por. J. Majka, 17 putk piechoty, Pruszków 1992.

${ }^{21}$ T. Suchorowski, Zarys historii wojennej 20-go Pułku Ułanów imienia Króla Jana III Sobieskiego, Warszawa 1929.

${ }^{22}$ By 1939, 5 heavy artilery regiment belonged to the Kraków garrison, while 10 heavy artillery regiments were located in Przemyśl

${ }^{23}$ K.L. Galster, Księga Pamiatkowa Artylerii Polskiej 1914-1939, Londyn 1975.

${ }^{24}$ Cropped sub-units of the AK gendarmerie were not planned for the current battle. Appropriate tasks for the gendarmerie were foreseen only at the time of the country's uprising and liberation. See: J. Marszalec, Ochrona porzadku i bezpieczeństwa publicznego w Powstaniu Warszawskim, Warszawa 1999, p. 40.

25 The 22nd Infantry Division - from 1925, the 22nd Infantry Division - had its command in Przemyśl. The 24th Infantry Division was formed in 1921. In 1939, the division's command was stationed in Jarosław.

${ }^{26}$ R. Gilewski, Zarys historji wojennej 5-go Pułku Strzelców Konnych, Warszawa 1931.

27 Orders of the inspector, Cpt. Eukasz Ciepliński, analogously to the assumptions of the entire plan for reconstruction of the armed forces, took into account the pre-war dislocation of the Polish Army. The exception was the failure to take into account the motorized brigade, although before 
The AFR plan required many details to be taken into account. Reconstructed units had to be provided with barracks. In Rzeszów - as the dislocation message said - the offices and institutions important for the army were to be found. In the building of the barracks in Batory Street, it was planned to locate - as it was before the war - the District Control Command; the edifice of the former Jewish folk house in Tennenbaum Street was planned for the command of the HA Rzeszów, headquarters of quartermaster services and organizational and administrative unit. Bearing in mind the considerable number of mobilized Home Army soldiers, five military hospitals (two surgical, one ophthalmic, one internal and one skin-venereal) ${ }^{28}$; were thought to be launched; the location of POW camps (officers and soldiers) and warehouses (intendent, motor equipment, transport materials, sanitary equipment, sapper) was established ${ }^{29}$.

With regard to prisoner-of-war camps, three rallying points for German prisoners were planned in Rzeszów; each branch was to provide one assembly point. In addition, it was necessary to take control of the German camps where prisoners from the Red Army were staying. In the Rzeszów region in the summer of 1943, such camps for Soviet prisoners of war were located in Majdan Królewski, in Dębski Porąb, and Wojsław. The instructions for the uprising stated: „With the existing Soviet [...] prisoners of war, change the guards, if possible, supply them with food, do not let them spread around. Announce that the Polish authorities will soon organize their return to their homeland ${ }^{30}$ ".

The mobilization unit of the HA Rzeszów District Command ${ }^{31}$ was guided by the First Lieutenant. Józef Król („Krzywy”), then Capt. Adam Mazurek („Wojbor”) and Lieutenant N.N. „Mucha”. The deputy mobilization officer was N.N. „Kmicic”. The mobilization unit prepared a perspective list of administrative and organizational tasks for the first and second stage of reconstruction of the armed forces. It combined special AFR guidelines, exercise instructions, and mobilization tables ${ }^{32}$. It foresaw first the ,ordering of offices and equipment and the device" of the Rzeszów District Supplementary Command ${ }^{33}$, and in turn the implementation of posters, preparation of messages and mobilization decrees. It was anticipated that the duties of the Command were to direct the mobilization of the army and the

September 1939 in Rzeszów, the command and part of the subunits of the 10th Motorized Cavalry Brigade were colonel. Stanisława Maczka. A motorized brigade - some documents say about the division - was to be reconstructed by the Mielec HA Inspectorate. By the way, it is worth mentioning that on the battlefields of September 10 BK there were 16 speed artillery squadrons from the first artillery regiment from Stryj. See G. Ostasz, Inspectorate of the UAS-HA Rzeszów in plans...

${ }^{28}$ Before the war, there was a garrison hospital in Rzeszów at Hoffmanowa St., and from the midtwenties the Garrison Chamber of Sick. Compare: J. Majka, Szpital garnizonowy [in:] Encyklopedia Rzeszowa, Rzeszów 2011, p. 812.

${ }^{29}$ RSA, group108, ref. 140, Attachment no. 1 to AFR, Komunikat dyslokacyjny; G. Ostasz, Gotowość do powstania powszechnego rzeszowskiej podziemnej armii (1941-1944), „Prace Historyczno-Archiwalne", vol. XXV, Rzeszów 2013, p. 188.

${ }^{30}$ Instrukcja powstania, collection of G. Brzęk.

${ }^{31}$ In the spring of 1944, the mobilization unit of the HA Rzeszów District Command was already full. G. Ostasz, Gotowość do powstania powszechnego...

32 Protokót zdawczo-odbiorczy K.O. „20”, oddajacy - „Andrzej”, odbierajacy - „Twardy”, collections of W. Składzień

${ }^{33}$ Before the war, the Rzeszów District Command Restoration was located at St. Batory in the so-called barracks of Głowacki. 
formation of prisoner-of-war camps, supervision of the garrison detention, the development of sentry plans, inventory of war achievements ${ }^{34}$.

The scope of duties of the mobilization unit of the Rzeszów District was quite ambitious. The employees were distinguished by meticulousness in fulfilling the tasks assigned to them. In the autumn of 1943, second lieutenant Król prepared an act of mobilization for the time after the victorious uprising. The mobilization act referred to ,the inactive state of all permanent service officers, non-commissioned officers of the permanent service, state officials and lower state officers, who on September 1, 1939 were on a full-time basis or served in the District Supplementary Command"35. The implementation of this announcement was a guarantee of genuine military mobilization. Strictly speaking, both the guarantee of the creation of officers of the reconstructed units and the incarnation of four trained vintages first, and then, depending on the needs, subsequent years. The plan allowed mobilization among the recent prisoners of stalags and oflags as well as the collection of volunteers. Although they do not take part in conspiracy, they report „during the [insurgency] action,” they must be considered as soldiers of active service ${ }^{36}$.

Groups of officers, non-commissioned officers and soldiers according to military specialties were needed. The tedious clerical work of the underground cells of the DSC hampered the principle of strict conspiracy in its own way. There were delays in the preparation of appropriate censuses from the institutions. Hence, in periodic orders, orders from the circuit command for an inventory of cavalrymen, artillerymen, sapper-pioneers, communications officers, drivers, etc. ${ }^{37}$.

The Rzeszów Home Army Inspectorate together with the Przemyśl HA Inspectorate was preparing to reconstruct the 24th Infantry Division. Although the draft of the general uprising - i.e. „Operational Report No. 154” - was replaced by a plan of increased subversive action under the code name „Burza”, there were no major changes in the issue of reconstruction of the armed forces. The ,framework guidelines of the AFR" provided for two options: the first - the formation of units „quiet, a secretive manner”, the second - „open formation", but still more attention was paid to the first option. He assumed that the existing branches would be used on the ,framework of formed units”. The HA platoons will grow to so-called full-time positions so that companies, battalions and regiments can be formed; of course, in designated areas of rebounds and concentration with planned connectivity and supply $^{38}$.

The details were included in the order No. 4-0 of Colonel Edward Godlewski („Garda”), commander of the HA District of Kraków; marked July 26, 1944. He recommended both the Commandant of the HA Rzeszów Sub-District and all inspectors of the district:

„The disclosure of larger branches in the district should take place: grouping of the 6th Infantry Division in the area of Kraków, grouping of 1 Podhalanska Rifle Regiment in the

\footnotetext{
${ }^{34}$ RSA, group 108, ref. 140, Chronologiczna tablica czynności na I-szy okres mobilizacji (OSZ); ibidem, Chronological table of activities for the II mobilization period (AFR); Protokót zdawczoodbiorczy K.O. „20”, oddajacy - „Andrzej”, odbierający - „Twardy”, collection of W. Składzien ${ }^{35}$ RSA, group 108, ref. 140, Obwieszczenie, z rozkazu Komendanta Obwodu - „Krzywy” oficer mobilizacyjny.

${ }^{36}$ RSA, group 108, ref. 139, Wytyczne do OSZ inspektora kpt. Cieplińskiego z lutego 1944 r.

${ }^{37}$ Institute of National Remembrance Branch in Krakow [hereinafter: INR Kr], collection of Andrzej T-10, k. 74, Rozkaz okresowy nr 12, 122, IX.43, Bór.

${ }^{38}$ RSA, group 108, ref. 139, Framework guidelines for AFR.
} 
Nowy Sącz area, grouping of the 24 Infantry Division in the Rzeszów-Przemyśl region, grouping of the 22nd Infantry Division in the Jasło-Sanok area, the Krakow grouping Cavalry Brigades in the Miechów area, a group of armored divisions in the area of the Mielec Inspectorate. The disclosure of other units than the infantry should take place in larger clusters in areas designated by the district commandant or at infantry assemblies. I recommend to all units to give numbers and basic names in accordance with the OSZ plan, report to the district command the proposals for casting commanders of regiments, giving the rank, pseudonym, previously occupied position in the conspiracy and a short opinion" 39 .

It is understood that the order of the commander of the Krakow HA District Colonel Godlewski confirmed the instructions of the Rzeszów HA Inspectorate regarding the reconstruction of the 24 Infantry Division (17th Infantry Regiment, 5th Rifle Regiment and 20 Uhlan Regiment). Although it is not known when the order was sent to the addressees, it can certainly be said that during the „Burza” none of the districts of the Rzeszów Inspectorate of Home Army used neither the numbers nor the names of the units played. The HA Rzeszów, instead of the 17th Infantry Regiment and 20 Uhlan Regiment, created 5 assemblies; the units of the Kolbuszowa District of the Home Army did not use the name of the 4th battalion of the 17th Infantry Regiment, HA Dębica District was not the 5th regiment of riflemen, but groups (units). Obviously, none of the district commanders called himself the commander of the regiment or battalion, but the commander of all HA's forces of the region ${ }^{40}$. Only Colonel Kazimierz Putek („Zworny”), commander of the Rzeszów Home Army sub-circle, was the commander of the 24th Infantry Division of the Home Army, Cpt. Ciepliński (,Pług”) and the commander of the Operational Group separated from this division. The 24th Infantry Division of the Home Army was determined by Colonel Putek, soldiers of the Rzeszów and Przemyśl Inspectorate, while the name of the Operational Group of the 24th Infantry Division of the HA, Capt. Ciepliński gave branches to the Rzeszów Inspectorate. Information about the „stormy” battles of I, II and III battalions of 17 infantry regiment of the HA was included in the communiqué of the command of the Operational Group 24 Infantry Division of the HA of July 28, $1944^{41}$.

All that has been presented so far seems to suggest that the „stormy" order of the commander of the district reached the sub-commander and HA Inspectorate of Rzeszów, whereas only some commander of the wards $\mathrm{s}^{42}$ and the commander of the units assigned to the „Burza” received it. This hypothesis is confirmed by the following annex to the order of Colonel Putek; dated 29 July 1944:

„1. Command 22 ID of the Home Army in the region 0/14 [the HA Jasło Inspectorate] - includes citizen Grzywa [Col. Zdzisław Zajączkowski, Inspector of the Home Army Headquarters]. Until his arrival, he leads the Provincial Headquarters 0/14 alternately. It forms

39 Order of Colonel Godlewski of July 26, 1944 for the command of the Rzeszów HA Sub-District and inspectorates, a copy of the document in the collection of G. Ostasz.

${ }^{40}$ Most likely, the commanders of reconstructed regiments and battalions would become (somehow automatically) according to the assumptions of the previous plans of the AFR commanders of wards, or in the case of a larger number of regiments or battalions through a given circuit - their deputies and officers who held higher positions in command.

${ }^{41}$ Statement of the Operational Group Command 24 of the Polish Home Army on 28.VII.1944, collection of G. Ostasz.

${ }^{42}$ Kolbuszowa district of the HA began using battalion and company names only after the "Burza" campaign. G. Ostasz, Gotowość do powstania powszechnego... 
basically 0/14, receiving supplements from III and IV / 13 [Przewów and Łańcut districts from the Inspectorate of the HA Przemyśl].

2. Command 24 ID of the Home Army in the area 0/11 and 0/13 [Rzeszów and Przemyśl inspectorates] covers me. He forms it basically 0/11, receiving supplements from I and II / 13 and 0/12 [the HA Przemyśl and HA Oblast Jarosław from the AK Inspectorate of Przemyśl and Inspectorate of the HA Mielec].

3. The armored brigade ${ }^{43}$ in the area of $1 / 11$ will be occupied by Wilk [N.N.]. The 0/11 inspector will report whether it is possible, otherwise he will provide suitable candidates.

4. Designated above inspectors forming large units will present their proposals for the cast of regimental commanders, giving the rank, pseudonym, previous function in conspiracy and a brief opinion.

5. The number is valid and basic names and composition (divisional units, according to the plan of the AFR).

6. I pay special attention to communication:

a. with me by all [...] means [...], special connections by $0 / 11$. [...]

b. communication with neighbors according to previous orders 44 ".

Points 4 and 5 show that Colonel Putek knew and fulfilled the order no. 4-0 of the commander of the HA District of Kraków. They are, after all, the appropriate parts of the order of Colonel Godlewski. It seems not accidental in point 2, Colonel Putek confirms the assumption of the command of the 24th Infantry Division of the Home Army, formed from soldiers of the inspectorate of 0/11 (Rzeszów) and two circuits: III/13 (Przeworsk) and IV/ 3 (Łańcut), from the inspectorate 0/13 (Przemyśl), supplemented with surpluses from the districts of Przemyśl and Jarosław, inspectorate 0/13 and inspectorate 0/12 (Mielec).

The general uprising was been realized. Its plan, however, was not lost. It became the starting point of the so-called subversive action with the code name „Burza”.

The military and political situation that arose in the territories of the Republic after the „Burza” - although easy to predict - surprised the headquarters of the HA's districts and subdivisions, the Warsaw Home Army Headquarters, the „headquarters” in London. Without developing the context, it is worth mentioning that the plan to restore the armed forces was still valid. This is evidenced by the report of the Przemyśl inspector, and also the deputy commander of the sub-circle, Lieutenant Colonel Antoni Dębski („Radwan”) on the appointment of cpt. Tadeusz Wawrzkiewicz („Baca”) a mobilizing officer 24 ID HA ${ }^{45}$. In September 1944, the AFR foundations were used in the Rzeszów region during the preparation of a large action of armed disclosure towards the Soviets ${ }^{46}$. In addition, some district commanders and inspectorates, preparing „stormy” reports, sent data on the reconstruction

${ }^{43}$ The brigade of the armored brigade was supposed to be 5 regiment of horse riflemen reconstructed by the HA Dębica District. On the other hand, the "stormy" order of Colonel Godlewski spoke about the armored division, for which the area of the Mielec Inspectorate was designated as the place of discovery.

44 Attachment to the order of Colonel Putek from July 29, 1944 to the inspectors, a copy in the collection of G. Ostasz. Compare: G. Ostasz, Gotowość do powstania powszechnego...

45 Captain Wawrzkiewicz was until August 23, 1944 the commander of the AK Łańcut District. Major Sławomir Holubek ("Rawicz") received this function after him. INR Kr, collections of Andrzeja Zagórski, T-3, k. 125, 0/13 do VIII/0014, mp. dn. 23 VIII 44 r., Radwan.

${ }^{4}$ See: G. Ostasz, A. Zagórski, Podokręg AK Rzeszów. Plan zbrojnego ujawnienia w świetle dokumentów (sierpień - wrzesień 1944 roku), Rzeszów 1999. 
of the armed forces to the command of the Rzeszów HA Sub-District. In this way, they fulfilled the orders of spring 1944. August 19, 1944, Capt. Tadeusz Zieliński („Obuch”) reported that the reconstruction of the 3rd Infantry Regiment of the Legions and the platoon of gendarmerie intended for the 24th Infantry Regiment of the Home Army was in full swing ${ }^{47}$. In turn, on 16 September, the inspector of Mielec presented Colonel Putek: ,list of non-commissioned officers of various types of arms (for AFR)" and „list of communication materials, (for the AFR cases)" 48 . The implementation of the AFR concerned the briefing of the sub-circle command of August 25, 1944. However, on the one hand, the failure of talks with the Soviets, on the other hand the mobilization by the Polish Committee of National Liberation crossed out the hopes for further battle of the HA units as the Polish Army. However, in early 1945 - in the Rzeszów HA Sub-range - the reconstruction plan of the armed forces became a pretext for the „mobilization” of the infantry division forced by the Soviets ${ }^{49}$.

\section{REFERENCES}

1. AK w dokumentach, vol. II, Czerwiec 1941 - kwiecień 1943, Londyn 1973.

2. AKw dokumentach, vol. VI.

3. Armia Krajowa w dokumentach 1939-1945, vol. VI, Uzupetnienia, Londyn 1989.

4. Bauer P., Garnizon leszczyński we wrześniu 1939 r., Leszno 1983.

5. Central Military Archive in Warszawa Rembertów, reference number III / 21/9, Tables of the Armed Forces in the country.

6. Chronological table of activities for the II mobilization period (AFR); Protokót zdawczo-odbiorczy K.O. „20”, oddajacy - „Andrzej”, odbierajacy - „Twardy”, collection of W. Składzień.

7. Galster K.L., Księga Pamiątkowa Artylerii Polskiej 1914-1939, Londyn 1975.

8. Gilewski R., Zarys historji wojennej 5-go Pułku Strzelców Konnych, Warszawa 1931.

9. Instrukcja powstania, collection of G. Brzęk.

10. Majka J., 17 putk piechoty, Pruszków 1992.

11. Majka J., Brygada motorowa płk. Maczka: 10. Brygada Kawalerii 1937-1939, Rzeszów 2004.

12. Majka J., Garnizon Rzeszów w latach 1918-1939, Rzeszów 2005.

13. Majka J., Szpital garnizonowy [in:] Encyklopedia Rzeszowa, Rzeszów 2011.

14. Marszalec J., Ochrona porzadku i bezpieczeństwa publicznego w Powstaniu Warszawskim, Warszawa 1999.

15. Ney-Krwawicz M., Powstanie powszechne w koncepcjach i pracach Sztabu Naczelnego Wodza i Komendy Gtównej Armii Krajowej, Warszawa 1999.

16. Olejarz T., Dzieje logistyki wojsk lądowych w latach 1944-1988 na przykładzie 9. Dywizji, Rzeszów 2013.

\footnotetext{
${ }^{47}$ INR Kr, collections of Andrzeja Zagórski, T-4, k. 29, 012 do m9, 19.8.1944, godz. 20.00, Obuch.

${ }^{48}$ Ibidem, k. 84, P1 do X1, mp. 16.9.44, godz. 7.00, Obuch. In the report of September 28, 1944, Capt. Zieliński presented a "quantitative list of a number of [other] arms [excluding] [...] for the case of AFR. Ibidem, T-4, k. 97, P do X, 28.9.44, godz. 7.00, Obuch.

${ }^{49}$ Compare G. Ostasz, Podziemna armia...
} 
17. Oral account of M. Wałęga (Rzeszów), 22 September 1998.

18. Ostasz G., Zagórski A., Podokręg AK Rzeszów. Plan zbrojnego ujawnienia w świetle dokumentów (sierpień - wrzesień 1944 roku), Rzeszów 1999.

19. Ostasz G., Gotowość do powstania powszechnego rzeszowskiej podziemnej armii (1941-1944), „Prace Historyczno-Archiwalne”, vol. XXV, Rzeszów 2013.

20. Ostasz G., Inspektorat ZWZ-AK Rzeszów w planach powstania powszechnego i odtwarzania sit zbrojnych, „Scientific Papers of RUT” 1991.

21. Ostasz G., Obwód ZWZ-AK Rzeszów. Konspiracja wojskowa i „Burza”, Rzeszów 1992.

22. Ostasz G., Podziemna armia. Podokręg AK Rzeszów, Rzeszów 2010.

23. Ostasz G., Z dziejów „Rozbratla”-Obwodu AK Rzeszów, Rzeszów 2003.

24. Polskie Sity Zbrojne w drugiej wojnie światowej, vol. 3, Armia Krajowa, Londyn 1950.

25. Protokół zdawczo-odbiorczy K.O. „20”, oddający - „Andrzej”, odbierajacy - „Twardy”, collections of W. Składzień

26. Sanojca A., Reconstruction of the Armed Forces in the Country, typescript, Institute of History of the Polish Academy of Sciences in Warsaw.

27. State Archives in Rzeszów [hereinafter: RSA], group 108, ref. 139, Wytyczne do OSZ inspektora kpt. Cieplińskiego z lutego 1944 r. Also in February 1944, orders for the reconstruction of the armed forces (the so-called mobilization orders) were issued by the remaining inspectors of the Rzeszów HA Sub-range. RSA, group 108, ref.119, to Kmdtów Obwody, Jagra, 3 February 1944.

28. Study of Polish Underground in London [abbrev.:SPU], ref. 2.3.2.11.2, Depesza-szyfr, L.dz. 852/Op, „Lawina” - wyjaśnić z OSZ, 10.VI.44.

29. Suchorowski T., Zarys historii wojennej 20-go Pułku Ułanów imienia Króla Jana III Sobieskiego, Warszawa 1929.

30. Zarzycki W., Z Wilna do Workuty. Wspomnienia komendanta garnizonu Okręgu Wileńskiego AK, Warszawa 2011.

\section{RZESZOWSKI GARNIZON ARMII KRAJOWEJ W PLANACH ODTWARZANIA SIE ZBROJNYCH}

Artykuł jest próbą ukazania roli konspiracyjnego garnizonu Armii Krajowej w Rzeszowie w okresie okupacji niemieckiej 1939-1944. Odtworzono przygotowania oraz zadania garnizonu związane z planem powstania powszechnego w Inspektoracie ZWZ-AK Rzeszów. Omówiono również główne zadania wynikające z zakładanej mobilizacji i tak zwanego odtwarzania sił zbrojnych, to jest próby uformowania regularnych oddziałów Wojska Polskiego nawiązujących do tradycji sprzed września 1939 r. Opisano szczegółowe ustalenia dla garnizonu rzeszowskiego wynikające z rozkazów Naczelnego Wodza z Londynu, ale również krajowych struktur dowódczych Armii Krajowej, które obejmowały również odbudowę obiektów koszarowych oraz innych wojskowych instytucji i obiektów. Przedstawiono organizację i strukturę konspiracyjnej Rejonowej Komendy Uzupełnień, służb kwatermistrzowskich, jak również garnizonowych szpitali. Autorzy dokonali oceny szans mobilizacyjnych, ale też bojowych oddziałów AK Inspektoratu Rzeszów w ramach powstania powszechnego, a potem akcji „Burza”. Tekst przynosi ponadto opis realnego stanu odtwarzania sił zbrojnych i formowania tak zwanych wielkich jednostek Armii Krajowej - dywizji 
piechoty, brygad kawalerii, pułków piechoty - na bazie regularnych oddziałów wojskowych w lecie 1944 r. Poruszono również zagadnienie akcji zbrojnego ujawnienia sił Armii Krajowej we wrześniu 1944 r., które nawiązywało do planu odtwarzania sił zbrojnych.

Słowa kluczowe: Wojsko Polskie, garnizon, Armia Krajowa.

DOI: $10.7862 /$ rz.2018.hss.7

Przestano do redakcji: styczeń $2018 \mathrm{r}$.

Przyjęto do druku: kwiecień 2018 r. 
